\title{
Community Participation Towards A Sustainable Thematic Kampung in Semarang
}

\author{
Hartati Sulistyo Rini ${ }^{1}$, Atika Wijaya ${ }^{2}$, Hasna Farras Elias Ridhwan ${ }^{3}$, Nisa Hafizhotus Syarifah ${ }^{4}$ \\ \{hartatisulistyorini@mail.unnes.ac.id ${ }^{1}$, atika.wijaya@mail.unnes.ac.id², hasnafarras96@ gmail.com ${ }^{3}$, \\ nisahsyarifah@gmail,com $\left.{ }^{4}\right\}$ \\ 1,2,3,4 Universitas Negeri Semarang, Indonesia
}

\begin{abstract}
Thematic Kampung is a development program initiated by the city government of Semarang, Central Java since 2016. This program aims to alleviate poverty in urban areas by exploring community-based of local resources. The implementation of this program depends on the participation of its community. However, community participation in one thematic kampung may differ to others. Some determinant factors could influence the differences in community participation. This article aims to compare the different forms of community participation in developing thematic kampung in Semarang. Based on that information, we could identify a strategy to improve community participation in developing a more sustainable thematic kampung in Semarang. This study will use a qualitative approach, and the data is collected through observation, in-depth interviews, document analysis, and Focus Group Discussion (FGD). The subject of this study is people from various thematic kampung in Semarang. This study is important and interesting to collect some ideas on the strategy to improve community participation to succeed in the development program.
\end{abstract}

Keywords: Community Participation, Semarang City, Sustainable City, Thematic Kampung

\section{Introduction}

Poverty in urban areas has become a major issue among the regional governments in Indonesia. The modern image and advanced civilization of city or town sometimes affected by poverty, for example, slum areas that look dirty and not suitable with modern buildings. Therefore, many policies tried to address the poverty problem in urban areas. The national government launched many programs aims to alleviate poverty such as Social Protection Cards and National Program of Community Empowerment (PNPM Mandiri) [1]. Meanwhile, in Semarang, Central Java Province, the city government developed a program called thematic kampung since 2006 to address poverty and in urban areas.

Thematic kampung is an integration of poverty alleviation program, strengthening local resources, improving physical facilities, as well as a part of tourism development. For the city government of Semarang, this program is part of the welfare improvement program for urban people in Semarang. Through this program, many kampungs (Kelurahan/Village) are revitalized based on their characteristic and potency. In this program, participation from local people as the main factor of the program to be succeed. People participation could improve the program and at the same time strengthen people's capacity [2], [3]. Participation becomes an essential part of community development in order to achieve goals in every development [4].

Many local governments focused on developing a special interest in tourism in their region to improve regional economics. Therefore, the program of thematic kampung appears in other 
cities also in Indonesia such as in Malang. The program of thematic kampung in Semarang differs from what in Malang city, East Java province. According to [2], thematic kampung in Semarang focused on community empowerment, which is encouraged to optimize local potential. Moreover, slum areas are revitalized physically and rebranding their image into specific thematic, for example, Thematic Kampung of Bandarjo [5]. In Malang, public participation is encouraged since the beginning of the development through the thematic kampung contest in which communities were encouraged to submit a proposal on how to develop their neighborhood with thematic kampung [6].

Through thematic kampung, the local potential and uniqueness characters such as social culture, architectural building, and local craft products could be explored and presented well for the tourists [7]. Therefore, these kind of kampung has two functions as a place to live for the community and a community-based tourism for commercialisation [8]. By encouraging public participation in developing thematic kampung, it does not only support the local community in improving their welfare but also strengthen the community. Todays ${ }^{6}$ developmental paradigm see human no longer as a subject, but as an active actor who can determine goals, control resources and direct the process, this paradigm called as people centered development [9].

This paper aims to explain the forms of community participation of thematic kampung by comparing Kampung Jawi and Kampung Batik in Semarang, which are part of thematic kampung program by the city government of Semarang. From the comparison, we could next identify the strategy on how improving community participation to develop a more sustainable thematic kampung in Semarang. In this case, humans and the community as the main actors of development are very important, especially considering that this thematic kampung is a default program from the government and that is top-down. The community becomes the key to the implementation of various activities carried out in the development of this thematic kampung. Without the role of the community, the sustainability of this program becomes very risky to be continued and even has the potential to stop in the middle of the whole process.

\section{Research Method}

This study employs a qualitative research approach to understand the forms of community participation in developing thematic kampung in Semarang city. The data collection process was undertaken in 2018 - 2019 in two thematic kampungs, namely Kampung Jawi in Kalialang, Sukerejo Village, Gunungpati Subdistrict and Kampung Batik Rejomulyo Village, Semarang Timur Subdistrict, both located in Semarang city, Central Java Province, Indonesia. These two thematic kampungs are chosen based on their representativeness and characteristics, among others thematic kampung in Semarang city. Using the constructivist comparing context method, it assumed that every case is unique. This method tries to find the meaning of something by comparing with another thing, which is not identical or see-through inside out [10]. Moreover, this article will explain the forms of community participation by comparing how does the participation developed in two thematic kampungs, Kampung Jawi and Kampung Batik.

In this study, we employ three main data collection methods. First, in-depth interviews were used to gain a comprehensive view of the community participation in Kampung Jawi and Kampung Batik. The informants were chosen by purposive sample consists of members of community groups in each kampung, administrative staffs in each kampung, staffs from the Regional Development Planning Agency of Semarang City, and staffs from the Tourism and Culture Office of Semarang City. Second, non-participant observation was done particularly to 
observe the activities related to community participation in Kampung Jawi and Kampung Batik. Third, we analyzed documents from governmental offices related to the program of thematic kampung and documents from the management of thematic kampung.

During the data collection process, we continuously crosschecked the information that we had previously obtained from the informants. All the data had been collected; then, we analyzed using the descriptive analysis to obtain thorough perspective about the improvement of community participation to realize a sustainable thematic kampung in Semarang city, Central Java.

\section{Result and Discussion}

The findings in this study will focus on three things: 1) community participation in each stage of programs, 2) the role of local leaders and communities, and 3) community behavior in responding to ongoing activities in the kampung. This discussion part will be presented in the comparative way of two thematic kampungs of Kampung Jawi and Kampung Batik.

\subsection{Community Participation In Implementing Thematic Kampung}

As a government program, the implementation of the thematic kampung depends on the participation of the community. The program, which has been designed in such a way as an alternative to alleviating poverty in urban communities, creates a space for community participation to become part of solving problems in their daily lives with the support of the government budget. There are three stages that becomes the arena of community participation in the implementation of this thematic kampungs as follows.

a) Planning

In the planning stage, community participation can be seen in the activities of identifying the products and arranging the programs. However, there is slightly different process happened in Kampung Jawi and Kampung Batik. In the process of identifying the products, Kampung Jawi's people are more focused on ideas triggered by a few people. These initial ideas even centered only on one person who had the idea on how to develop the kampung area based on the local potential of the local community. This idea mainly driven by Pak Siswanto, an artist who specialized in Javanese arts and also a chief hamlet (Ketua RW). He, then proposed the formation of the Kampung Jawi to the Semarang city government. This name, Kampung Jawi, based on the products that will be developed by people were based on Javanese traditional arts, especially traditional music and dance arts. Support for local potential developed in this village will also be enriched with local food products, such as gendar pecel, and other snacks.

After the process of identifying the prime products of the kampung was exceeded, the next process was the preparation of the Kampung Jawi's programs. Through various considerations, Pak Siswanto then packed the thematic kampung in Kalialang with the theme of Javanese tradition conservation. Local abilities that emerge are Javanese dance, gamelan and karawitan, tambourine/rebana, traditional games, construction of supporting facilities, and making village icons that form the Jaten market, which taken place in the riverbank area and is easily accessible by visitors. To support this idea, Pak Siswanto invited children and young people in the village to participate in the art practice. Pak Siswanto asked his friends who are dance trainers from the Semarang state university (UNNES) to teach the children Javanese 
traditionl dance. The trainers were paid by Pak Siswanto from his personal money. After those children could dance, they had been performed at various events in the village. The cost of the performance was also came from his pocket. This was done to gain sympathy and support from parents in the village. For gamelan skills, Pak Siswanto involved more teenagers and young people. Although there are protests related to the use of tambourines owned by the elderly, Pak Siswanto was able to explain and give understanding to the community that this activity would make young people and teenagers have positive activities, such as increasing self-confidence, improving skills, and even bring the positive image of the Kampung Jawi. Therefore, the community could understand and support the positive intention of Pak Siswanto in developing Kampung Jawi. Meanwhile, for revitalizing the physical appearance, they built a gate to Kampung Jawi, planted flower, and drew murals. Those physical development were built using the Semarang city government budget assistance.

On the other hand, the community participation in Kampung Batik Rejomulyo tend to be slightly different. The idea came from the village government due to the program of city government. In a word, the establishment of Kampung Batik is a top-down program from the government not from the community. Various meetings are held to plan and arrange the program and what kind of assistance is needed to support the program. This process enters the identification stage of the program determination. This meeting was the beginning of the plan for community empowerment activities carried out after the Batik kampung became a Thematic kampung. The results of the meetings were a submitted proposal to the Rejomulyo local government. This proposal gone through selection conducted in stages, starting from the District of East Semarang to the Office of Planning and Development of Semarang City (Bappeda). Kampung Batik which was existed since the time of the Dutch government, was revived through batik training in 2006-2008 organized by City government.

Entering the next process is the preparation of the program. A kampung meeting was held to determine what programs would be offered in the thematic kampung. Based on the local potential of batik, the program was compiled such as batik making and selling, batik training for tourists, batik training for local residents, submission of facility development, and construction of village icons, namely Kampung Djadoel. Systematic planning of community empowerment activities in Batik kampung is carried out at least once a month, through routine meetings (RW meetings). In addition, there were also other community meetings, there are community meetings, women social gathering, men social gathering and meetings of youth clubs. RW meetings are usually held in the RW hall at the end of the month after another meeting is held. RT meetings, PKK meetings and social gathering are held at the beginning or in the middle of the month. Each RT has different times according to the RT agreement. Through regular meetings of each RT, each RT in Kampung Batik decide own characteristics.

b) Implementation

In general, the implementation stage of thematic kampung program in Kampung Jawi and Kampung Batik gained interest and sympathy from the people or residents in both kampungs. Many residents showed their support and participate voluntarily in developing the kampung with innovative and interesting themes. However, community participation appearead in different forms and level in those kampungs.

In Kampung Jawi Kalialang, its residents participate and involve in four main program as thematic kampung. First, organizing the Jaten Market as an icon of Kampung Jawi twice a month on Sunday. The Jaten Market is created as a space for the community to show their local potential to the broader public. In this market, the residents of Kampung Jawi could participate by selling food, clothes and others stuffs. This market also provides spots for visitors to take their picture. Moreover, some performance of traditional Javanese arts can be 
found in this market. The interesting thing about this market is the means of transactions that using "kepeng" made from tile roof fraction, and not using Rupiah as an official Indonesian money. The visitors need to exchange their Rupiah into Kepeng first before doing the economic transaction. The uniqueness of Jaten Market has attracted many visitors to visit Kampung Jawi. Second, the performance of traditional arts. Although the activities of traditional arts first initiated by Pak Siswanto, the variety of arts performance keeps increasing and became the main attraction of Kampung Jawi. Not only presented traditional dance and rebana/tambourine, but also traditional games and gamelan. However, in this activities, people participation is still very limited and only restricted to children who willing to learn traditional dance and arts.

Third, the participation in regular trainings to support Kampung Jawi's events. Some trainers in this kampung are voluntary willing to teach visitors in gamelan, pranatacara (MC spesialized in Javanese language), traditional dance, and even traditional games. However, not many people either local residents or visitors want to learn the traditional arts and therefore this program is not well appreaciated by the community. In order to support the objective of Kampung Jawi as thematic kampung, some residents attended spesific trainings held by the City Government of Semarang such as photography workshop to promote Kampung Jawi in social media. Fourth, the participation in monthly and annual activities in Kampung Jawi. Among many programs, only the Jaten Market is well received and attracted many visitors in Kampung Jawi. The Jaten Market is involved local community groups, local artists, and local entrepeneurs. Some of the local products are presto bandeng, gethuk, gendar pecel, jamu powder etc. Currently, the community consider to produce souvenirs with the logo of Kampung Jawi such as ship replicas, key chains, rings or pendants from wood, and resins. The sustainability of the Jaten Market is supported by the voluntary work of the sellers who provide $10 \%$ of their income from the Jaten market for cleaning service and community funds. Community participation was also seen from residents who voluntary become the managers of Jaten Market. This group is called the Kepeng Fighters (Pejuang Kepeng) which have task to organizing the residents who want to sell their products or to performs in the Jaten market.

In the Kampung Batik Rejomulyo, the implementation of the thematic kampung also received support from residents, including in the administration of the Kampung Djadoel, training in making batik for visitors, performing art performances, maintaining the environment and waste management. Kampoeng Djadhoel was inaugurated on April 29, 2017. The concept of Kampoeng Djadhoel is an initiative from the community itself. The beginning of this program was made because people in Kampung Batik Tengah have many Jadul (Old Time) or antique items. Djadoel or vintage items were arranged and exhibited in a joglo house in the middle of the village. Kampoeng Djadhoel also held batik exhibitions every Sunday, batik training, and batik-themed murals. The residents actively participate in this program and uses funds from the community's contribution fee. Other attraction in Kampung Djadhoel are traditional puppets, masks, traditional crafts and toys. After Kampoeng Djadhoel became the icon of tourism in Kampung Batik, the funds for its development were no longer derived from residents' contributions, but instead came from cash from the profits obtained from tourists.

The next activity is batik training which was organized by the Batik kampung Association. People lcan earn to make batik in Saturday and Sunday from the experts, and hold meetings if there will be preparation for the event. This association coordinates the batik makers in Kampung Batik. Art performance are also an important part of the development of thematicbased people's participation. This show displayed in this kampung is a colossal theater. This colossal theater is an initiative of young people in Kampung Batik, which is coordinated through Karang Taruna (young people organization in village). This colossal theater tells 
about the history of Batik Village and to promote Kampung Batik so that can attract more tourists. The theater is held every October 19, which coincides with the burning of Kampung Batik in the past. From the scenario, facilities and administration of the colossal theater were done by the residents. Moreover, youth also actively participated in collected the funds by selling used goods and clothing. This activity has also been supported by the Semarang City Culture and Tourism Office.

The next activity in Kampung Batik is participation in maintaining the environment and waste management. The community conducts voluntary work to clean the environment by providing more trash bins, planting more plants and making gardens in their frontyard, painting their house with certain themes. The cost to revitalize the environment is from the community itself and for the routine maintenance, a Community Self-Help Group (KSM) is formed. The Kampung Batik community collaborated with students from the Faculty of Engineering, Diponegoro University (UNDIP) to create waste management from batik processing. Waste Water Management Installation (IPAL) is established to reduce the waste. The IPAL tool is made by students, while the community helps provide the need for experiments. Experiments were carried out at the RW hall. After the trial was succeed, batik artisans were coordinated through the Kampung Batik Association to manage batik waste produced using the IPAL tool. Some of these tools are in RW hall and there are also in the houses of several residents who are batik artisans.

c) Monitoring and Evaluation

This phase contain of two type of monitoring and evaluation. There are internal coordination and external evaluation. Internal coordination in each of these kampung also has distinctive characteristics which may differ from each other. In kampung Jawi, there are no special meetings among them, but they communicate the programs implementation routinely. They use the preparation time for activities to also conduct discussions on weekly, monthly, and annually agenda of activities. Regarding daily and weekly agendas, people are often involved in program visits, and gamelan exercises are also conducted once a week. For the monthly program is Pasar Jaten, and the annual program is Memetri Kampung Jawi. Memetri Kampung Jawi is the anniversary of kampung Jawi in the month of October, precisely on Legi Sunday. The activities carried out in the annual program are cultural carnival, and at night is followed by art performances, such as ketoprak.

On the other hand, internal coordination in kampung Batik is conducted periodically once a month which involves RT meetings, PKK (women), youth clubs. Coordination of empowerment activities in stalls or gazebos when residents are gathering. Kampung Batik residents feel that the inspiration for empowerment activities that will be carried out can be more easily found while chatting and relaxing together. The Rejomulyo Urban kampung government often supervises the Kampung Batik area to see the Kampung Batik empowerment and development activities. This is usually done when the kelurahan conducts activities in Kampung Batik.

External evaluation carried out in the Kampung Jawi in the form of annually product Expo by Bappeda, established stands of thematic kampung products. As for Kampung Batik, an annual evaluation was held with the Regional Work Meeting held by the Bappeda of Semarang City. The supervision is carried out by the village office and then will be reported to the Bappeda at the Semarang City Regional Work Meeting. It will report at a minimum every once a year. The community in kampung Batik was also asked to make a report on the activities related to the development of the area to the kelurahan.

\subsection{The role of leaders and local communities}


Based on the previous explanation, the role of leaders and local communities in each village is important and has some differences among two kampungs. For Kampung Jawi, the leader of kampung development has a very big role. Several people as informal leaders, they have special capability in art: traditional music, dance, art performance. The local community in this kampung is Pokdarwis (Kelompok Sadar Wisata). This entity is a group of people who are aware of the importance of developing the tourism sector, and at the same time drive for the growth of tourism in the area. Local communities want to be part of tourism development decisions, because they can protecting community interests, increasing transparancy and accountability [11]. The development leader of Kampung Jawi Kalialang acted as the initiator of the idea and development. The responsibility of developing thematic kampung seems to be centralized in the hands of initiators and idea developers, because the community does not yet have the awareness to actively participate in thematic village development activities.

Whereas in the Kampung Batik Rejomulyo, the leader plays a role as a coordinator to improve the program. Local communities that develop are Pokdarwis, PKK, and youth clubs. Leaders in this case, more focus on developing kampung batik and prioritizing coordination functions among the local community. The huge amount of community participation in each activity emerged there, has resulted a more flexibility in developing of thematic kampung. It is because of the wide scope of community development ideas, and the amount of people enthusiasm to be involved in implementing the program with the collaboration and synergy from various parties.

\subsection{People's response}

The findings of this study focused on participation in the context of community involvement in each program implementation and community involvement in preparing funding. In the Kampung Jawi, many people who have not been actively involved in its development. The development of Javanese culture faces a negative stigma from most people who have a religious background. Other community members began to be involved in implementing various programs when these art activities began to show the results and were packaged into interesting shows and were often staged at various events. The outsiders of this communities began to recognize that the hallmark of this village was in the performance of traditional Javanese art. For funds, they rely on the community's voluntary and independent funds that the leader issues himself.

On the other hand, the phenomenon that occurs in the Kampung Batik is the opposite. People are actively involved in generating dissent in arranging programs, and somehow attention competing from the leader to improve the program. This difference of opinion usually occurs at the planning stage of empowerment activities in Kampung Batik. This is because in the planning stage, residents in Kampung Batik participate to express their opinions. So that many opinions were conveyed by residents there. In fact, sometimes if there is a difference of opinion in planning an activity, it can lead to conflict on parties who disagree. In responding to differences of opinion, the people in Kampung Batik held official meetings.

Competition between residents in Kampung Batik is the presence of citizens who always want to look superior to others. These differences of opinion occured because some people want to be directly involved and become leaders in the implementation of several programs. Their presence in this meeting and differences of opinion in the forum colored the dynamics of community empowerment that happened. This is felt to be very exciting as well as a challenge 
in the process of developing this local tourism. This competition also led to unfair business competition among batik traders. This is because the batik traders sell their merchandise at a price that is much cheaper than the others. These prices make the merchandise sold far more than other batik traders. To resolve this challenge, it usually takes place informally in advance through small talk between residents. if deemed necessary, this can also be brought to the meeting forum so that it can be resolved by involving the wider community. sometimes the results of this meeting cannot satisfy all parties, but over time they can accept the decisions made at the meeting. For funding, residents voluntarily collect and among themselves, even collectively sell used goods, and seek sponsors from relevant parties even from stakeholders related to the activities they will undertake.

\section{Conclusion}

Thematic kampung which initiated by the city government of Semarang aims to address poverty in urban areas. Not only revitalized the physical appearance of slum area, but also the most essential is to empower the community. Although most of the thematic kampung in Semarang is top-down policy, the community participation is emphasized and encouraged in all stages of program from planning, implementation, monitoring to evaluation. The sustainability of thematic kampung is depend on the active participation of its community. Moreover, the role of leaders in each thematic kampung also important to encourage and even mobilize the community participation. This study important to learn that different level and form of community participation could contribute to the sustainability aspect of thematic kampung.

\section{References}

[1] Z. R. Amni and N. Diyah, "Triple Helix in the Poverty Reduction Policy Based on Community Empowerment in Semarang City," in E3S Web Conf., 2018, vol. 73, pp. $1-4$.

[2] H. S. Rini, "The Dynamics of Strengthening Socio-Economic Capacity of Rural Community Through Thematic Kampong in Semarang," in International Conference on Rural Studies in Asia (ICoRSIA 2018), 2019, pp. 149-143.

[3] M. Ngabiyanto, M. H. Susanti, and M. Setiajid, "Empowering and Developing The Local Potency Through Thematic Village in Semarang," in International Conference on Rural Studies in Asia (ICoRSIA 2018), 2019, pp. 5-7.

[4] Alfitri, Community Development: Teori dan Aplikasi. Yogyakarta: Pustaka Pelajar, 2011.

[5] H. Purnaweni, "Revitalization of Slum Area in Semarang City with Thematic Village Program -- A Case Study in Bandarharjo Village, Indonesia," in International Conference on Administrative Science (ICAS 2017), 2017, pp. 94-96.

[6] D. M. Utomo and D. I. Shofarini, "Improving community participation in planning through planning education: A case of Kampung Duren in Malang, Indonesia," Malang, 2017.

[7] W. Astuti, Qomarun, A. Febela, R. A. Putri, and D. W. Astuti, "Identification of Specific Characteristic of Kampung Jayengan as Community-based Industrial Tourism," in Procedia - Social and Behavioral Sciences, 2016, vol. 227, pp. 485492. 
[8] A. Nur Ramadhani, M. Faqih, and A. Hayati, "Inhabitant'S Sense of Place in the Context of Tourism Kampung," J. Archit., vol. 17, no. 2, pp. 151-168, 2018.

[9] F. T. Nasdian, Pengembangan Masyarakat. Jakarta: Yayasan Pustaka Obor Indonesia, 2014.

[10] J. W. Moses and T. L. Knutsen, Ways of Knowing: Competing Methodologies in Social and Political Research, Second Edi. New York: Palgrave Macmillan, 2012.

[11] M. Muganda, A. Sirima, and P. M. Ezra, "The Role of Local Communities in Tourism Development: Grassroots Perspectives from Tanzania," J. Hum. Ecol., vol. 41, no. 1, pp. 53-66, 2013. 